\title{
ANALISIS PERENCANAAN PAJAK UNTUK MENGHEMAT PENGELUARAN PAJAK PADA KANTOR NOTARIS ATAU PPAT (PEJABAT PEMBUAT AKTA TANAH)
}

\author{
Isnawati \\ Fakultas Ekonomi dan Bisnis Universitas Mataram \\ isnawati.isna@unram.ac.id \\ Artha Selamet Hidayat \\ Fakultas Ekonomi dan Bisnis Universitas Mataram
}

\begin{abstract}
Secara umum, pajak merupakan iuran rakyat kepada kas negara berdasarkan undangundang, sehingga bersifat memaksa, dengan tidak mendapat balas jasa langsung. Dalam upaya terus meningkatkan penerimaan pajak, maka berbagai upaya di lakukan pemerintah salah satunya terus melakukan renovasi terhadap undang-undang perpajakan baik itu Pajak Penghasilan (PPH), Pajak pertambahan nilai (PPN), dengan tujuan untuk mengoreksi celah dalam peraturan perpajakan dahulu. Salah satu dari undang-undang pajak penghasilan yaitu undang-undang No.36 tahun 2008 yang merupakan penyempurnaan undang-undang No.16 tahun 2000 tentang pajak penghasilan. Dalam undang-undang tersebut diharuskan bagi setiap wajib pajak dalam pemenuhan kewajiban perpajakannya, Menggunakan Self Asessment Sytem. Dalam penggunaan system ini diharapkan agar yang bersangkutan memiliki kesadaran terhadap kewajibannya, kejujuran menghitung, membayar pajak sesuai dengan peraturan perundang-undangan yang berlaku. Bagi perusahaan, pajak merupakan beban yang akan mengurangi laba bersih dan modal pada periode berikutnya maka dalam hal ini beberapa perusahaan mengenal istilah "perencanaan pajak ", dimana adalah serangkaian kegiatan yang dilakukan perusahaan dalam upaya menghemat pengeluaran pajaknya. Dari analisis tentang perencanaan pajak dan dengan adanya koreksi fiskal terhadap laporan keuangan Notaris NINING HERLINA SH.M.kn dapat ditarik kesimpulan yaitu perencanaan pajak yang efektif dapat dihasilkan melalui analisis terhadap laporan keuangan dengan cara melakukan koreksi yang maksimal terhadap laporan keuangan seperti dengan penyesuaian biaya-biaya komersil dapat dimaksimalkan untuk dikoreksi fiskal dengan mengikuti peraturan yang telah ditetapkan oleh pemerintah.
\end{abstract}

Kata Kunci : Wajib Pajak, Self Asessment Sytem,Perencanaan Pajak

\section{PENDAHULUAN}

Negara republik Indonesia merupakan negara hokum yang setiap kebijakannya berdasarkan pancasila dan undang-undang dasar 1945 yang menjunjung tinggi hak dan kewajiban setiap warga negarannya, sebagai pembiayaan negara. Negara republik Indonesia menepatkan pajak sebagai salah satu sumber pembiayaan utama. Secara umum, pajak merupakan iuran rakyat kepada kas negara berdasarkan undang-undang, sehingga bersifat memaksa, dengan tidak mendapat balas jasa langsung. Dalam upaya terus meningkatkan penerimaan pajak, maka berbagai upaya di lakukan pemerintah salah satunya terus melakukan renovasi terhadap undang-undang perpajakan baik itu Pajak Penghasilan (PPH), Pajak pertambahan nilai (PPN), dengan tujuan untuk mengoreksi celah dalam peraturan perpajakan dahulu. Salah satu dari undang-undang pajak penghasilan 
yaitu undang-undang No.36 tahun 2008 yang merupakan penyempurnaan undang-undang No.16 tahun 2000 tentang pajak penghasilan.

Dalam undang-undang tersebut diharuskan bagi setiap wajib pajak dalam pemenuhan kewajiban perpajakannya, Menggunakan Self Asessment Sytem, yaitu memberikan kepercayaan penuh terhadap wajib pajak untuk menghitung, memperhitungkan, menyetor, dan melaporkan sendiri hutang pajaknya. Dalam penggunaan system ini diharapkan agar yang bersangkutan memiliki kesadaran terhadap kewajibannya, kejujuran menghitung, membayar pajak sesuai dengan peraturan perundang-undangan yang berlaku. Bagi perusahaan, pajak merupakan beban yang akan mengurangi laba bersih dan modal pada periode berikutnya maka dalam hal ini beberapa perusahaan mengenal istilah "perencanaan pajak", dimana adalah serangkaian kegiatan yang dilakukan perusahaan dalam upaya menghemat pengeluaran pajaknya. Meminimalisasi beban pajak dapat dilakukan denga berbagai cara, mulai dari yang masih ada dalam bingkai praturan perpajakan sampai dengan upaya penghematan yang melanggar praturan perpajakan. Upaya meminimalisasi pajak sering disebut dengan perencanaan pajak ,melaksanakan kewajiban pembayaran pajak dengan jumlah yang sebenarnya sesuai peraturan perundangundangan perpajakan merupakan hal yang harus dipenuhi oleh isetiap subyek pajak suatu negara, dimana tindakan penyelewengan merupakan Dalam undang-undang tersebut diharuskan bagi setiap wajib pajak dalam pemenuhan kewajiban perpajakannya , Menggunakan Self Asessment Sytem,yaitu memberikan kepercayaan penuh terhadap wajib pajak untuk menghitung,memperhitungkan, menyetor,dan melaporkan sendiri hutang pajaknya. Dalam penggunaan system ini diharapkan agar yang bersangkutan memiliki kesadaran terhadap kewajibannya, kejujuran menghitung, membayar pajak sesuai dengan peraturan perundang-undangan yang berlaku. Bagi perusahaan ,pajak merupakan beban yang akan mengurangi laba bersih dan modal pada periode berikutnya maka dalam hal ini beberapa perusahaan mengenal istilah "perencanaan pajak " , dimana adalah serangkaian kegiatan yang dilakukan perusahaan dalam upaya menghemat pengeluaran pajaknya. Meminimalisasi beban pajak dapat dilakukan denga berbagai cara,mulai dari yang masih ada dalam bingkai praturan perpajakan sampai dengan upaya penghematan yang melanggar praturan perpajakan . Upaya meminimalisasi pajak sering disebut dengan perencanaan pajak ,melaksanakan kewajiban pembayaran pajak dengan jumlah yang sebenarnya sesuai peraturan perundang-undangan perpajakan merupakan hal yang harus dipenuhi oleh isetiap subyek pajak suatu negara, dimana tindakan penyelewengan merupakan tindakan melawan hokum, tetapi melakukan penghematan pajak akan sah sah saja asalkan selaras dengan ketentuan perpajakan yang disahkan dalam undang-undang perpajakan yang berlaku, perencanaan dilakukan dengan memanfaatkan pengecualian- pengecualian dan celah-celah perpajakan yang diperbolehkan oleh UU No.17 Tahun 2000 tentang pajak sehingga perencanaan pajak tersebut tidak dianggap sebagai pelanggaran yang akan merugikan wajib pajak sehingga tidak akan mengarah pada penggelapan pajak Bangsa Indonesia saat ini sedang mengalami masalah dari berbagai sector salah satu yang paling vital adalah pada sector ekonomi.

Di dalam kondisi ekonimi saat ini ,banyak perusahaan mengalami kebangkrutan, hal ini disebabkan beberapa factor .Diantaranya meningkatkan tingkat inflasi dan nilai tukar rupiah terhadap mata uang asing (dollar) yang mengalami penurunan,sebagai akibatnya perusahaan harus mengeluarkan biaya usaha yang besar untuk membiayai kegiatan usahanya ,tetapi dengan pengeluaran yang besar tersebut, kadangkala perusahaan tidak mendapat pendapatan yang sebanding dengan biaya yang dikeluarkannya, hal ini akan lebih terasa pada setiap perusahaan yang mempunyai pinjaman atau hutang dollar dalam jumlah yang besar, dalam hal ini perusahaan yang tergantung pada barang impor atau yang masih tergantung pada pihak asing. Dalam hal keadaan seperti ini ,maka menejer prusahaan harus dapat menentukan keputusan serta tujuan dari prusahaan yang dipegang . Tugas menejer prusahaan adalah mengambil keputusan yang didasarkan pada keterpaduan 
antara fungsi bisnis yang meliputi bidang pemasaran,produksi ,keuangan sumber daya manusia, penelitian serta pengembangan, dan fungsi menejerial yang meliputi perencanaan ,pengorganisasian penggerakan serta pengawasan ,berdasarkan masalah di atas maka sangat perlu pengkajian/pembahasan tentang ,"perencanaan pajak untuk menghemat pengeluaran pajak " yang tetap sesuai dengan peraturan perundang-undangan perpajakan yang sedang berlaku .

Notaris dan PPAT (Pejabat Pembuat Akta Tanah) Dalam pasal 1 angka 1 UUJN disebutkan bahwa definisi notaris adalah pejabat umum yang berwenang untuk membuat akta otentik dan kewenangan lainnya. Sedangkan definisi PPAT (Pejabat Pembuat Akta Tanah) tercatat dalam pasal 1 ayat 1 dari Peraturan Pemerintah Nomor 37 Tahun 1998 tentang Peraturan Jabatan Pejabat Pembuat Akta Tanah. PPAT atau Pejabat Pembuat Akta Tanah adalah pejabat umum yang diberikan kewenangan untuk membuat akta-akta otentik mengenai perbuatan hukum tertentu mengenai hak atas tanah atau Hak Milik Atas Satuan Rumah Susun.

\section{TUJUAN}

1. Untuk mengetahui praktek perencanaan pajak pada kantor notaris dan PPAT (Pejabat Pembuat Akta Tanah)

2. Untuk berbagi pengetahuan perpajakan dalam hal penghematan pajak yang sesuai dengan Undang-undang perpajakan.

\section{TELAAH LITERATUR DAN PENGEMBANGAN HIPOTESIS}

\section{Definisi Pajak}

Pajak merupakan iuran yang harus dibayarkan oleh setiap penduduk di Indonesia untuk negaranya dalam rangka pembangunan negara. Pajak dipungut berdasarkan undangundang. Asas ini sesuaidengan perubahan ketiga UUD 1945 pasal 23A yang menyatakan , "Pajak dan pungutan lain yang bersifat memaksa untuk keperluan negara diaturdalam undang-undang." Pengertian pajak menurut beberapa ahli :

a. Menurut Prof Dr Adriani,

Pajak adalah iuran kepada negara yangdapat dipaksakan, yang terutang oleh wajib pajak membayarnya menurutperaturan derngan tidak mendapat imbalan kembali yang dapat ditunjuksecara langsung.

b. Menurut Prof. DR. Rachmat Sumitro,SH,

pajak adalah iuran rakyat kepada kas negara (peralihan kekayaan dari kas rakyat ke sectorpemerintah berdasarkan undang-undang) dapat dipaksakan dengan tiadamendapat jasa timbal balik yang langsung dapat ditunjukkan dandigunakan untuk membiayai pengeluaran umum.Sedangkan

c. Menurut Sommerfeld Ray M., Anderson Herschel M., \&Brock Horace R, pajak adalah suatu pengalihan sumber dari sector swasta ke sector pemerintah, bukan akibat pelanggaran hukum, namunwajib dilaksanakan, berdasarkan ketentuan yang ditetapkan lebih dahulu,tanpa mendapat imbalan yang langsung dan proporsional, agarpemerintah dapat melaksanakan tugas-tugasnya untuk menjalankan pemerintahan.

Dari berbagai pengertian tersebut dapat disimpulkan bahwa ada beberapa unsur yang tidak dapat dipisahkan dari pengertian pajak tersebut, yaitu:

a. Pajak dipungut berdasarkan undang undang beserta aturanpelaksanaannya. 
b. Pajak memiliki sifat dapat dipaksakan, hal ini berarti jika terdapatpelanggaran atas aturan perpajakan dapat dikenakan sanksi.

c. Dalam pembayaran Pajak tidak dapat ditunjukan adanyakontraprestasi secara langsung oleh pemerintah

d. Pajak dipungut oleh pemerintah, baik pemerintah pusat, maupun olehpemerintah daerah. Pajak tidak dapat dipungut oleh pihak lain diluar pemerintah yang berorientasi kepada keuntungan.

e. Pajak yang dipungut dari masyarakat digunakan oleh pemerintah untuk membiayai pengeluaran-pengeluaran pemerintah dalam rangka menjalankan fungsi pemerintahan, baik rutin maupun pembangunan.

\section{Fungsi Pajak}

a. Fungsi anggaran (budgetair) Sebagai sumber pendapatan negara, pajak berfungsi untukmembiayai pengeluaranpengeluaran negara. Untuk menjalankan tugas-tugas rutin negara dan melaksanakan pembangunan, negaramembutuhkan biaya. Biaya ini dapat diperoleh dari penerimaan pajak.

b. Fungsi mengatur (regulerend) Pemerintah bisa mengatur pertumbuhan ekonomi melaluikebijaksanaan pajak. Dengan fungsi mengatur, pajak bisa digunakansebagai alat untuk mencapai tujuan.

c. Fungsi stabilitas

Dengan adanya pajak, pemerintah memiliki dana untuk menjalankan kebijakan yang berhubungan dengan stabilitas hargasehingga inflasi dapat dikendalikan, Hal ini bisa dilakukan antara laindengan jalan mengatur peredaran uang di masyarakat, pemungutan pajak, penggunaan pajak yang efektif dan efesien.

\section{Fungsi redistribusi pendapatan}

Yaitu pemanfaatan pajak untuk membuka lapangan pekerjaan. Dengan bertambahnya lapangan pekerjaan, maka semakin banyak pula penyerapan tenaga kerja sehingga pendapatan masyarakat pun dapat diperoleh secara merata. Demikianlah penjelasan singkat mengenai apa itu pajak dan fungsinya yang penting terhadap pembangunan bangsa dan negara

\section{Pajak Penghasilan.}

Pajak Penghasilan diatur dalam Undang- Undang Nomor 7 Tahun1983 tentang Pajak Penghasilan sebagaimana telah beberapa kali diubah terakhir dengan UndangUndang Nomor 17 Tahun 2000 tentang Perubahan Ketiga atas Undang-Undang Nomor 7 Tahun 1983 tentangPajak Penghasilan. Kemudian pemerintah mengubah lagi menjadiUndang-Undang no 36 Tahun 2008. Pajak penghasilan adalah pajak yang dibebankan pada penghasilan perorangan, perusahaan atau badan hukum lainnya yang diterima ataudiperoleh selama satu tahun pajak. Pajak penghasilan bisa diberlakukan tarif progresif, proporsional, atau regresif.

\section{Subyek Pajak Penghasilan}

Menurut UU PPh nomor 7 tahun 2000 pasal 2, yang menjadi subjekPPh adalah orang pribadi; warisan yang belum terbagi sebagai satukesatuan, menggantikan yang berhak; badan; dan bentuk usaha tetap (BUT). Subjek Pajak terdiri dari:

1. Subjek Pajak Dalam Negeri

a. Orang pribadi yang bertempat tinggal di Indonesiaatau yang berada di Indonesia lebih dari 183 (seratus delapan puluh tiga) hari dalam jangka waktu 12 (dua belas) bulan, atau yang dalam suatu tahun pajak berada di Indonesia dan mempunyai niat untuk bertempat tinggal di Indonesia.

b. Badan yang didirikan atau bertempat kedudukan di Indonesia, meliputi Perseroan 
Terbatas, perseroan komanditer,perseroan lainnya, Badan Usaha Milik Negara atau Daerah dengan namadan dalam bentuk apapun, firma, kongsi, koperasi, dana pensiun,persekutuan, perkumpulan, yayasan, organisasi massa, organisasi social politik atau organisasi yang sejenis, lembaga, bentuk usaha tetap dan bentuk badan lainnya termasuk reksadana.

c. Warisan yang belum terbagi sebagai satu kesatuan,menggantikan yang berhak.

\section{Subjek Pajak Luar Negeri}

a. Orang pribadi yang tidak bertempat tinggal diIndonesia atau berada di Indonesia tidak lebih dari 183 (seratus delapanpuluh tiga) hari dalam jangka waktu 12 (dua belas) bulan, dan badan yangtidak didirikan dan tidak bertempat kedudukan di Indonesia yangmenjalankan usaha atau melakukan kegiatan melalui BUT di Indonesia

3. Orang Pribadi yang tidak bertempat tinggal diIndonesia atau berada di Indonesia tidak lebih dari 183 hari dalam jangka waktu 12 bulan, dan badan yang tidak didirikan dan tidak bertempat kedudukan di Indonesia yang dapat menerima atau memperolehpanghasilan dari Indonesia bukan dari menjalankan usaha atau

4. melakukan kegiatan melalui BUT di Indonesia.

\section{Obyek Pajak Penghasilan}

Menurut UU PPh no. 7 tahun 2000 pasal 4, yang menjadi objek Pajak Penghasilan adalah penghasilan yaitu setiap tambahan kemampuan ekonomis yang diterima atau diperoleh Wajib Pajak (WP), baik yang berasal dari Indonesia maupun dari luar Indonesia, yang dapat dipakai untuk konsumsi atau untuk menambah kekayaan Wajib pajak yang bersangkutan dengan nama dan dalam bentuk apapun termasuk :

1. Penggantian atau imbalan berkenaan dengan pekerjaan atau jasa yangditerima atau diperoleh termasuk gaji, upah, tunjangan, honorarium, komisi, bonus, gratifikasi, uang pensiun atau imbalan dalam bentuklainnya kecuali ditentukan lain dalam Undang- undang Pajak Penghasilan

2. hadiah dari undian atau pekerjaan atau kegiatan dan penghargaan

3. laba usaha;

4. keuntungan karena penjualan atau karena pengalihan harta termasuk :

a. keuntungan karena pengalihan harta kepadaperseroan, persekutuan, dan badan lainnya sebagai pengganti saham ataupenyertaan modal

b. keuntungan yang diperoleh perseroan, persekutuan, dan badan lainnya karena pengalihan harta kepadapemegang saham, sekutu atau anggota

c. keuntungan karena likuidasi, penggabungan, peleburan, pemekaran, pemecahan atau pengambilalihan usaha

d. keuntungan karena pengalihan harta berupa hibah, bantuan atau sumbangan, kecuali yang diberikan kepada keluarga sedarahdalam garis keturunan lurus satu derajat, dan badan keagamaan atau badan pendidikan atau badan sosial atau pengusaha kecil, termasuk koperasi yang ditetapkan oleh Menteri Keuangan, sepanjang tidak ada hubungan dengan usaha, pekerjaan, kepemilikan atau penguasaan antara pihak pihak yang bersangkutan;

5. penerimaan kembali pembayaran pajak yang telah dibebankan sebagai biaya.

6. bunga termasuk premium, diskonto dan imbalan karena jaminanpengembalian utang

7. dividen dengan nama dan dalam bentuk apapun, termasuk dividen dariperusahaan asuransi kepada pemegang polis dan pembagian sisa hasilusaha koperasi

8. Royalt

9. sewa dan penghasilan lain sehubungan dengan penggunaan harta;

10. penerimaan atau perolehan pembayaran berkala 
11. keuntungan karena pembebasan utang, kecuali sampai dengan jumlahtertentu yang ditetapkan dengan Peraturan Pemerintah

12. keuntungan karena selisih kurs mata uang asing

13. selisih lebih karena penilaian kembali aktiva;

14. premi asuransi

15. iuran yang diterima atau diperoleh perkumpulan dari anggotanya yangterdiri dari WP yang menjalankan usaha atau pekerjaan bebas

16. tambahan kekayaan neto yang berasal dari penghasilan yang belum dikenakan pajak

\section{Pengecualian Obyek Pajak Penghasilan.}

1. Bantuan atau sumbangan termasuk zakat yang diterima oleh badanamil zakat atau lembaga amil zakat yang dibentuk atau disahkan oleh Pemerintah dan para penerima zakat yang berhak. Harta hibahan yang diterima oleh keluarga sedarah dalam garis keturunan lurus satu derajat, dan oleh badan keagamaan atau badan pendidikan atau badan atau pengusaha kecil termasuk koperasi yang ditetapkan oleh Menteri Keuangan, epanjang tidak ada hubungan dengan usaha, pekerjaan, kepemilikan, atau penguasaan antara pihakpihak

2. Warisan

3. Harta termasuk setoran tunai yang diterima oleh badan sebagai pengganti saham atau sebagai pengganti penyertaan modal

4. Penggantian atau imbalan sehubungan dengan pekerjaan atau jasa yang diterima atau diperoleh dalam bentuk natura dan atau kenikmatan dari Wajib Pajak atau Pemerintah.

5. Pembayaran dari perusahaan asuransi kepada orang pribadi sehubungan dengan asuransi kesehatan, asuransi kecelakaan, asuransi jiwa, asuransi dwiguna dan asuransibeasiswa.

6. Dividen atau bagian laba yang diterima atau diperoleh perseroan terbatas sebagai WP Dalam Negeri, koperasi, BUMN atau BUMD dari penyertaan modal pada badan usaha yang didirikan dan bertempat kedudukan di Indonesia dengan syarat.

a. dividen berasal dari cadangan laba yang ditahan, dan

b. bagi perseroan terbatas, BUMN dan BUMD yang menerima dividen, kepemilikan saham pada badan yang memberikan dividen paling rendah $25 \%$ (dua puluh lima persen) dari jumlah modal yang disetor dan harus mempunyai usaha aktif di luar kepemilikan saham tersebut.

7. Iuran yang diterima atau diperoleh dana pensiun yang pendiriannya telah disahkan oleh Menteri Keuangan, baik yang dibayar oleh pemberi kerja maupun pegawai.

8. Penghasilan dari modal yang ditanamkan oleh dana pensiun dalam bidang-bidang tertentu yang ditetapkan dengan Keputusan Menteri Keuangan.

9. Bagian laba yang diterima atau diperoleh anggota dari perseroankomanditer yang modalnya tidak terbagi atas saham-saham, persekutuan, perkumpulan, firma dan kongsi.

10. Bunga obligasi yang diterima atau diperoleh perusahaan reksa danaselama 5 (lima) tahun pertama sejak pendirian perusahaan ataupemberian izin usaha.

11. Penghasilan yang diterima atau diperoleh perusahaan modal ventura.

\section{Tarif Pajak Penghasilan}

a. Pajak progresif adalah tarif pemungutan pajak dengan persentase yang naik dengan semakin besarnya jumlah yang digunakan sebagai dasar pengenaan pajak, dan kenaikan persentase untuk setiap jumlah tertentu setiap kali naik.

b. Tarif Degresif (Menurun) adalah tarif pemungutan pajak yang persentasenya semakin kecil bila jumlah yang dijadikan dasar pengenaan pajak semakin besar.

c. Tarif Proporsional adalah tarif pajak yang menggunakan persentase tetap tanpa memperhatikan jumlah yang dijadikan dasar pengenaan pajak.

d. Tarif Tetap adalah tarif pemungutan pajak yang besar nominalnya tetap tanpa 
memperhatikan jumlah yang dijadikan dasar pengenaan pajak.

Tarif Pajak Badan tahun 2009Tabel 1.1

\begin{tabular}{l|l}
\hline Lapisan Penghasilan Kena Pajak & Tarif Pajak \\
\hline Penghasilan hingga Rp 50 juta & $10 \%$ \\
\hline Penghasilan > Rp 50 juta - Rp 250 juta & $15 \%$ \\
\hline Penghasilan > Rp 250 juta - Rp 500 juta & $25 \%$ \\
\hline Penghasilan > Rp 500 juta & $30 \%$ \\
\hline
\end{tabular}

Berlaku efektif sejak 1 Januari 2009 wajib Pajak Badan dikenakan Tarif tunggal sebesar $30 \%$ yang kemudian diturunkan menjadi $28 \%$, dan nantinya akan menjadi $25 \%$ pada tahun 2010. Untuk WP Badan Masuk Bursa diberikan tarif 5\% lebih rendah dari tariff yang berlaku.

\section{Pajak Penghasilan Pasal 25}

1. Besarnya angsuran pajak dalam tahun pajak berjalan yang harus dibayar sendiri oleh Wajib Pajak untuk setiap bulan adalah sebesar PajakPenghasilan yang terutang menurut Surat Pemberitahuan Tahunan Pajak Penghasilan tahun pajak yang lalu dikurangi dengan:

a. Pajak Penghasilan yang dipotong sebagaimana dimaksud dalam Pasal 21 dan Pasal 23 serta Pajak Penghasilan yang dipungut sebagaimana dimaksud dalam Pasal 22;dan

b. Pajak Penghasilan yang dibayar atau terutang di luar negeri yang boleh dikreditkan sebagaimana dimaksud dalam Pasal 24. dibagi 12 (dua belas) atau banyaknya bulan dalam bagian tahun pajak. 14

2. Besarnya angsuran pajak yang harus dibayar sendiri oleh Wajib Pajak untuk bulanbulan sebelum batas waktu penyampaian Surat Pemberitahuan Tahunan Pajak Penghasilan, sama dengan besarnya angsuran pajak untuk bulan terakhir tahun pajak yang lalu

3. Apabila dalam tahun pajak berjalan diterbitkan surat ketetapan pajak untuk tahun pajak yang lalu, maka besarnya angsuran pajak dihitung kembali berdasarkan surat ketetapan pajak tersebut dan berlaku mulai bulan berikutnya setelah bulan penerbitan surat ketetapan pajak.

4. Direktur Jenderal Pajak berwenang untuk menetapkan penghitungan besarnya angsuran pajak dalam tahun pajak berjalandalam hal-hal tertentu, yaitu:

a. Wajib Pajak berhak atas kompensasi kerugian.

b. Wajib Pajak memperoleh penghasilan tidak teratur

c. Surat Pemberitahuan Tahunan Pajak Penghasilan tahun yang lalu disampaikan setelah lewat batas waktu yang ditentukan

d. Wajib Pajak diberikan perpanjangan jangka waktu penyampaian Surat Pemberitahuan Tahunan Pajak Penghasilan.

e. Wajib Pajak membetulkan sendiri Surat Pemberitahuan Tahunan Pajak Penghasilan yang mengakibatkan angsuran bulanan lebih besar dari angsuran bulanan sebelum pembetulan.

f. terjadi perubahan keadaan usaha atau kegiatan Wajib Pajak.

5. Penghitungan besarnya angsuran pajak bagi Wajib Pajak baru, bank,Badan Usaha Milik Negara, Badan Usaha Milik Daerah, dan Wajib Pajak tertentu lainnya. termasuk Wajib Pajak orang pribadi pengusaha tertentudiatur dengan Keputusan Menteri Keuangan.

6. Bagi Wajib Pajak orang pribadi yang bertolak ke luar negeri wajibmembayar pajak yang ketentuannya diatur dengan Peraturan Pemerintah.

7. Pajak yang telah dibayar sendiri dalam tahun berjalan oleh Wajib Pajak orang pribadi pengusaha tertentu merupakan pelunasan pajak yang terutang untuk tahun pajak yang bersangkutan, kecuali apabila Wajib Pajak yang bersangkutan menerima atau memperoleh penghasilan lainyang tidak dikenakan Pajak Penghasilan yang bersifat final menurut Undang-undang ini. 


\section{Pajak Penghasilan Pasal 29}

Pajak penghasilan (pph) pasal 29 adalah mengenai kredit pajak, pelunasan kekurangan pembayaran pajak, surat pemberitahuan tahunandan pengembalian kelebihan pembayaran pajak yang disebutkan bahwa apabila pajak yang terutang untuk suatu tahun pajak ternyata lebih besar dari pada jumlah kredit pajak, maka kekurangan pajak yang terutang harus dilunasi selambat-lambatnya pada akhir bulan ketiga sesudah tahun pajak yang bersangkutan berakhir, sebelum Surat Pemberitahuan Tahunan disampaikan.

\section{Perencanaan Pajak}

Perencanaan pajak (tax planning) merujuk kepada proses merekayasa usaha dan transaksi Wajib Pajak agar utang pajak berada dalam jumlah yang minimal, tetapi masih dalam bingkai peraturan perpajakan. Namun demikian, perencanaan pajak juga dapat diartikan sebagai perencanaan pemenuhan kewajiban perpajakan secara lengkap, benar, dan tepat waktu sehingga dapat secara optimal menghindar pemborosan sumber daya.

\section{Aspek Formal Dalam Perencanaan Pajak}

a. Kewajiban mendaftarkan diri untuk memperoleh Nomor Pokok WajibPajak (NPWP)dan Nomor Pengukuhan Pengusaha Kena Pajak (NPPKP)

b. Menyelenggarakan pembukuan atau pencatatan

c. Memotong dan/atau memungut pajak

d. Membayar pajak

e. Menyampaikan Surat Pemberitahuan.

\section{Aspek Material Dalam Perencanaan Pajak}

Basis penghitungan pajak adalah objek pajak. Dalam rangka optimalisasi alokasi sumber dana, manajemen akan merencanakan pembayaran pajak yang tidak lebih dan tidak kurang. Untuk itu, objek pajak harus dilaporkan secara benar dan lengkap.

\section{Tujuan Dilakukan Perencanaan Pajak}

Menurut Lumbatoruan $(2000 ; 483)$, fungsi perencanaan pajak adalah Secara teoritis perencanaan pajak adalah bagian dari manajemen pajak. Perencanaan pajak disini tidak sama dengan perencanaan yang merugikan penerimaan Negara. Tujuan manajemen pajak dasarnya serupa dengan tujuan manajemen keuangan yaitu samasama bertujuan untuk memperoleh likuiditas dan laba yang cukup. Lebih lanjut. Lumbantoruan 2000;483) menjelaskan tujuan dan fungsi perencanaan yaitu melakukan kewajiban perpajakan, dan usaha efisiensi.

\section{Strategi Umum Perencanaan Pajak}

1. Tax Avoidance

Tax Avoidance atau penghindaran pajak adalah suatu usaha Transaksi yang ditujukan untuk meminimalkan biaya pajak dengan Memanfaatkan kelemahan kelemahan ketentuan perpajakan suatu Negara. Dengan demikian, usaha tersebut dilakukan secara legal karena tidak melanggarketentuan pajak.

2. Tax Evasion

Tax Evasion atau penggelapan pajak adalah suatu usaha untuk meringankan biaya pajaknya dengan memanipulasi penghasilan yang diperolehnya secara illegal atau melanggar ketentuan hokum perpajakan yang berlaku.

3. Tax Saving

Tax saving merupakan upaya efisiensi beban pajak melalui pemilihan alternatif pengenaan pajak dengan tarif yang lebih rendah. Misalnya, perusahaan yang memiliki penghasilan kena pajak lebih dari Rp. 100 jutadapat melakukan perubahan pemberian 
natura kepada karyawan menjaditunjangan dalam bentuk uang. Penghematan pajak atas perubahan iniberkisar antara 5\%-25\% untuk penghasilan karyawan sampai dengan Rp.200 juta.Menunda pembayaran kewajiban pajak Menunda pembayaran kewajiban pajak tanpa melanggar peraturan yangberlaku dapat dilakukan melalui penundaan pembayaran PPN. Penundaanini dilakukan dengan menunda penerbitan faktur pajak keluaran hingga batas waktu yang diperkenankan, khususnya untuk penjualan kredit.Dalam hal ini, penjual dapat menerbitkan faktur pajak pada akhir bulan berikutnya setelah bulan penyerahan barang. Mengoptimalkan kredit pajak yang diperkenankan Wajib Pajak sering kurang memperoleh informasi mengenai pembayaranpajak yang dapat dikreditkan yang merupakan pajak dibayar dimuka.Misalnya, PPh Pasal 22 atas pembelian solar dan/atau impor dan FiskalLuar Negeri atas perjalanan dinas pegawai.

4. Tax Treaty

Tax treaty atau yang lebih dikenal dengan Perjanjian Penghindaran Pajak Berganda (P3B) adalah perjanjian perpajakan antara dua negara yang dibuat dalam rangka meminimalisir pemajakan berganda dan berbagaiusaha penghindaran pajak. Perjanjian ini digunakan oleh penduduk dua negara untuk menentukan aspek perpajakan yang timbul dari suatu transaksi di antara mereka. Penentuan aspek perpajakan tersebut dilakukan berdasarkan klausul-klausul yang terdapat dalam tax treaty yang bersangkutan sesuai jenis transaksi yang sedang dihadapi

\section{Tahapan Dalam Perencanaan Pajak}

a. Menganalisis informasi yang ada (analyzing the existing data base)

b. Membuat satu atau lebih model kemungkinan jumlah pajak (designingone or more possible tax plans)

c. Mengevaluasi pelaksanaan perencanaan pajak (evaluating a tax plan)

d. Mencari kelemahan dan memperbaiki kembali rencana pajak (debugging the tax plans)

e. Memutakhirkan rencana pajak (updating the tax plan)

\section{Perencanaan Pajak untuk Pajak Penghasilan (PPh) 19}

Laba Akuntansi Kaitannya dengan Penghasilan Kena Pajak Dalam akuntansi terdapat masalah yang timbul jika berkaitan dengan pajak penghasilan. Masalahmasalah tersebut timbul dalam standar atau aturan yang digunakan dalam pelaporan akuntansi dengan pelaporan pajak sering kali tidak sama atau saling bertentangan. Perbedaan tersebut harus dilakukan rekonsiliasi fiskal, sehingga nantinya dapat diketahui penghasilan kena pajak perusahaan.Akuntansi di Indonesia membuat peraturan untuk perlakuan akuntansi untuk pajak penghasilan, yang tertuang dalam PSAK 46 yangmengatur:

a. Mempertanggung jawabkan konsekuensi pajak pada periode berjalan dan periode mendatang untuk hal-hal sebagai berikut:

b. Pemulihan Nilai catat aktiva dan pelunasan nilai catat kewajiban yang disajikan dalam neraca.

c. Transaksi atau kejadian lain dalam periode berjalan yang diakui dan disajikan dalam laporan komersial perusahaan.

d. Pengakuan aktiva pajak tangguhan yang berasal dari sisa kerugian yang belum dikompensasikan, penyajian pajak penghasilan di dalam laporan keuangan komersial dan pengungkapan informasi yang berhubungan dengan pajak penghasilan.

\section{Biaya yang Boleh Dikurangkan dari Penghasilan Bruto}

Didalam pajak, terdapat biaya yang dapat dikurangkan untuk mengurangi biaya pajak yang terutang yang biasa dikenal dengan biaya fiskal. Menurut Undang-Undang PPh no 17 tahun 2000, pasal 6 ayat (1), yang termasuk biaya fiskal yaitu:

1. Biaya untuk mendapatkan, menagih, dan memelihara penghasilan. termasuk biaya 
pembelian bahan, biaya berkenaan dengan pekerjaan atau jasa termasuk upah, gaji, honorarium, bonus, gratifikasi, dan tunjangan yang diberikan dalam bentuk uang, bunga, sewa, royalti, biaya perjalanan,biaya pengolahan limbah, premi asuransi, biaya administrasi, dan pajakkecuali pajak penghasilan.

2. Penyusutan atas pengeluaran untuk memperoleh harta berwujud dan amortisasi atas pengeluaran untuk memperoleh hak atas biaya lain yang mempunyai masa manfaat lebih dari 1 (satu) tahun.

3. iuran kepada dana pensiun yang pendiriannya telah disahkan oleh Menteri Keuangan.

4. kerugian karena penjualan atau pengalihan harta yang dimiliki dan digunakan dalam perusahaan atau yang dimiliki untuk mendapatkan, menagih, dan memelihara penghasilan.

5. kerugian dari selisih kurs mata uang asing.

6. biaya penelitian dan pengembangan perusahaan yang dilakukan di Indonesia.

7. biaya bea siswa, magang, dan pelatihan.

8. piutang yang nyata-nyata tidak dapat ditagih, dengan syarat

9. telah dibebankan sebagai biaya dalam laporan laba rugi komersial

10. telah diserahkan perkara penagihannya kepada Pengadilan Negeri atau Badan Urusan Piutang dan Lelang Negara (BUPLN) atau adanya perjanjian tertulis mengenai penghapusan piutang/pembebasan utang antara kreditur dan debitur yangbersangkutan.

a. telah dipublikasikan dalam penerbitan umum atau khusus; dan 21

b. Wajib Pajak harus menyerahkan daftar piutang yang tidak dapat ditagih kepada Direktorat Jenderal Pajak, yang pelaksanaannya diatur lebih lanjut dengan Keputusan Direktur Jenderal Pajak.Apabila penghasilan bruto setelah pengurangan sebagaimana yang telah disebutkan tadi masih didapat kerugian, maka kerugian tersebut dikompensasikan dengan penghasilan mulai tahun pajak berikutnya berturut-turut sampai dengan 5 (lima) tahun. Kepada orang pribadi sebagai Wajib Pajak dalam negeri diberikan pengurangan berupa Penghasilan Tidak Kena Pajak.

\section{Biaya yang Tidak Boleh Dikurangkan dari Penghasilan Bruto}

Biaya yang tidak dapat dikurangkan dari penghasilan bruto, menurut UndangUndang no 17 tahun 2000, pasal 9 ayat (1) yaitu :

a. pembagian laba dengan nama dan dalam bentuk apapun seperti dividen, termasuk dividen yang dibayarkan oleh perusahaan asuransi kepada pemegang polis, dan pembagian sisa hasil usaha koperasi.

b. biaya yang dibebankan atau dikeluarkan untuk kepentingan pribadi pemegang saham, sekutu, atau anggota.

c. pembentukan atau pemupukan dana cadangan kecuali cadangan piutang tak tertagih untuk usaha bank dan sewa guna usaha dengan hakopsi, cadangan untuk usaha asuransi, dan cadangan biaya reklamasi untukusaha pertambangan, yang ketentuan dan syarat-syaratnya ditetapkan dengan Keputusan Menteri Keuangan.

d. premi asuransi kesehatan, asuransi kecelakaan, asuransi jiwa, asuransi dwiguna, dan asuransi bea siswa, yang dibayar oleh Wajib Pajak orangpribadi, kecuali jika. dibayar oleh pemberi kerja dan premi tersebut dihitung sebagai penghasilan bagi Wajib Pajak yang bersangkutan;

e. penggantian atau imbalan sehubungan dengan pekerjaan atau jasa yang diberikan dalam bentuk natura dan kenikmatan, kecuali penyediaan makanan dan minuman bagi seluruh pegawai serta penggantian atau imbalan dalam bentuk natura dan kenikmatan di daerah tertentu dan yangberkaitan dengan pelaksanaan pekerjaan yang ditetapkan dengan Keputusan Menteri Keuangan.

f. jumlah yang melebihi kewajaran yang dibayarkan kepada pemegangsaham atau kepada pihak yang mempunyai hubungan istimewa sebagai imbalan sehubungan dengan 
pekerjaan yang dilakukan.

g. harta yang dihibahkan, bantuan atau sumbangan, dan warisan sebagaimana dimaksud dalam Pasal 4 ayat (3) huruf a dan huruf $b$, kecuali zakat atas penghasilan yang nyatanyata dibayarkan oleh Wajib Pajak orang pribadi pemeluk agama Islam dan atau Wajib Pajak badan dalam negeri yang dimiliki oleh pemeluk agama Islam kepada badan amil zakatatau lembaga amil zakat yang dibentuk atau disahkan oleh Pemerintah

h. Pajak Penghasilan

i. biaya yang dibebankan atau dikeluarkan untuk kepentingan pribadiWajib Pajak atau orang yang menjadi tanggungannya

j. gaji yang dibayarkan kepada anggota persekutuan, firma, atau perseroan komanditer yang modalnya tidak terbagi atas saham.

k. sanksi administrasi berupa bunga, denda, dan kenaikan serta sanksipidana berupa denda yang berkenaan dengan pelaksanaan perundang-undangan di bidang perpajakan.

\section{Sanksi Perpajakan}

Tata cara pengenaan pajak dan sanksi-sanksi berkenaan denganpelaksanaan Undangundang ini dilakukan sesuai dengan Undang-undangNomor 6 Tahun 1983 tentang Ketentuan Umum dan Tata CaraPerpajakan sebagaimana telah diubah terakhir dengan UndangundangNomor 16 Tahun 2000.

\section{Pelaporan dan Pembayaran Pajak Penghasilan}

Tata cara pelaporan dan pembayaran pajak dilakukan sesuaidengan Undangundang Nomor 6 Tahun 1983 tentang Ketentuan Umumdan Tata Cara Perpajakan sebagaimana telah diubah terakhir denganUndang-undang Nomor 16 Tahun 2000. Untuk pelaporan, sebagaimana telah ditentukan dengan Undang-Undang no 16 tahun 2000, pasal 3 ayat(3) yang berisi tentang Batas waktu penyampaian Surat Pemberitahuan adalah.

a. untuk Surat Pemberitahuan Masa, paling lambat 20 (dua puluh) hari setelah akhir Masa Pajak;

b. untuk Surat Pemberitahuan Tahunan, paling lambat 3 (tiga) bulan setelah akhir Tahun Pajak.

Untuk Pembayaran dan penyetoran pajak juga diatur dalam Undang-Undang no 16 tahun 2000, pasal 9 ayat (1) yang isinya mengenai "Menteri Keuangan menentukan tanggal jatuh tempo pembayaran dan penyetoranpajak yang terutang untuk suatu saat.

\section{HASIL PENELITIAN DAN PEMBAHASAN}

\section{Analisis Perencanaan Pajak untuk menghemat pengeluaran pajak paa kantor NOTARIS NINING HERLINA. SH, MKn}

Setelah dilakukannya koreksi fiskal terjadi perbedaan pada laba sebelum pajak, dimana yang dihasilkan makin meningkat. Untuk mengatasi kenaikan laba maka biayabiaya yang dikeluarkan perusahaan dapat dijadikan biaya pengurang bruto (biaya fiskal). Perencanaan pajak yang dilakukan menggunakan cara-cara yang legal dan sesuai dengan peraturan perpajakan. Cara yang dilakukan adalah menghindari sanksi-sanksi perpajakan dengan melihat celah-celah didalam peraturan-peraturan yang ditetapkan. Perencanaanperencanaan yang mungkin dapat diterapkan oleh perusahaan adalah sebagai berikut:

1. Jika biaya listrik dan telepon digunakan untuk kegiatan operasional perusahaan, maka perusahaan dapat pengurangan penghasilan bruto. Perusahaan melakukan koreksi positif karena biaya telepon yang dikeluarkan perusahaan untuk biaya pulsa 3 orang karyawan dengan 3 jabatan sebesar Rp 300.000,00 per bulan dan tergantung kebutuhan pemakaian dalam kegiatan operasional perusahaan. Biaya dapat dibebankan sebagai biaya perusahaan sebesar $50 \%$ dari biaya perolehan yang sebagaimana telah dimaksud 
dalam Keputusan Direktur Jenderal Pajak No. KEP-220/PJ/2002 tentang perlakuan penghasilan atas biaya pemakaian telepon seluler. Perencanaan pajak seharusnya dilakukan perusahaan adalah menggantikan biaya voucher handphone para karyawan dengan tunjangan lain dalam bentuk uang tunai, hal ini bisa menjadi penambahan penghasilan tetapi bagi perusahaan menjadi pengurang penghasilan sehingga dapat menghemat beban pajak penghasilan. Hal ini sesuai dengan Undang-Undang PPh No. 36 Tahun 2008 tentang biaya-biaya yang dapat menjadi pengurang penghasilan bruto, salah satunya adalah tunjangan dalam bentuk uang tunai.

2. Biaya pemeliharaan kendaraan bermotor perlu dikoreksi sebesar $50 \%$. Perencanaan pajak dilakukan untuk biaya pemeliharaan kendaraan bermotor agar seluruh biaya pemeliharaan dapat menjadi pengurang penghasilan bruto dengan cara memberikan tunjangan lain-lain dalam bentuk uang tunai kepada karyawan. Hal ini sesuai dengan Pasal 6 ayat (1) a Undang-Undang PPh tentang biaya-biaya yang menjadi pengurang penghasilan bruto, salah satunya adalah tunjangan dalam bentuk uang tunai.

3. Biaya entertainment sebesar Rp $20.400 .900,00$ tahun 2019. Maka perencanaan pajak dilakukan perusahaan dengan membuat daftar nominatif biaya entertainment agar biaya tersebut tidak dianggap fiktif sehingga bisa dibiayai perusahaan untuk mengurangi penghasilan bruto. Daftar nominatif dibuat secara lengkap atas transaksi yang terjadi dan dilampirkan dalam SPT Tahunan PPh.

4. Untuk biaya rumah tangga kantor dikeluarkan perusahaan dalam rangka memenuhi setiap kebutuhan dan keperluan perusahaan seperti tissue, pewangi ruangan, alat kebersihan, alat tulis kantor (ATK) dan lain sebagainya tidak dapat dijadikan biaya dalam laporan keuangan pajak. Biaya ini merupakan biaya yang masuk dalam grey area, sehingga berpotensi untuk dilakukan koreksi fiskal positif. Oleh karena itu perencanaan pajak dilakukan atas biaya rumah tangga dengan melampirkan bukti- bukti yang terkait dengan transaksi, maka biaya rumah tangga kantor dapat diakui sebagai biaya karena perpajakan mengakui suatu transaksi apabila transaksi mempunyai buktibukti yang mendukung.

5. Biaya dikeluarkan perusahaan dalam rangka kesejahteraan karyawan. Karyawan merupakan aset penting perusahaan, oleh karena itu tidak heran kalau setiap perusahaaan mengeluarkan biaya tambahan untuk meningkatkan kesejahteraan karyawannya. Tapi perlu diperhatikan bahwa tidak semua biaya dapat dijadikan pengurang penghasilan bruto. Karena itu, sebaiknya perusahaan mengupayakan semaksimal mungkin memberikan kesejahteraan kepada karyawannya dalam bentuk tunjangan karena biaya ini merupakan biaya fiskal sesuai dengan pasal 6 ayat (1) huruf a Undang-Undang PPh. Perusahaan menetapkan sistem reimbursement dalam biaya kesehatan karyawan, dimana biaya ini harus dilakukan koreksi fiskal positif karena merupakan pemberian natura atau kenikmatan kepada karyawan sesuai dengan pasal 9 ayat (1) huruf e Undang-Undang PPh. Perencanaan pajak seharusnya dilakukan perusahaan dengan memberi tunjangan kesehatan bagi karyawan. Bagi karyawan tunjangan bisa menjadi tambahan penghasilan sesuai dengan KEP-545/PJ/2000 bagi perusahaan menjadi pengurang penghasilan bruto (deductible expense) sesuai dengan pasal 6 ayat (1) a Undang-Undang PPh.

6. Untuk biaya lain-lain yang sebagian besar mencakup sumbangan dan hibah yang dikeluarkan perusahaan tidak boleh dijadikan sebagai pengurang bruto, karena sumbangan tidak berhubungan langsung dengan kegiatan usaha perusahaan.

\section{Rekonsiliasi Fiskal Sebelum dan Sesudah Perencanaan Pajak}

Rekonsiliasi fiskal adalah proses penyesuaian laba komersial yang berbeda dengan ketentuan fiskal yang dapat menghasilkan penghasilan neto dan laba sesuai ketentuan pajak. Rekonsilisasi fiskal dilakukan oleh Wajib Pajak karena terdapat perbedaan penghitungan, khususnya laba menurut akuntansi (komersial) dengan laba menurut 
perpajakan (fiskal). Laporan keuangan komersial ditujukan untuk menilai kinerja ekonomi dan keadaan finansial sektor swasta, sedangkan laporan keuangan fiskal lebih ditujukan untuk menghitung pajak. Penyebab perbedaan laporan keuangan komersial dan laporan keuangan fiskal karena terdapat perbedaan prinsip akuntansi, perbedaan metode dan prosedur akuntansi, perbedaan pengakuan penghasilan dan biaya, serta perbedaan perlakuan penghasilan dan biaya.Berikut ini adalah tabel laporan laba-rugi Kantor Notaris dan PPAT NINING HERLINA SH.M.kn yang disusun dengan laporan keuangan komersil dan laporan koreksi fiskal.

Tabel 1.2

Kantor Notaris dan PPAT NINING HERLINA SH.M.kn Rekonsiliasi Perhitungan Laba Rugi Komersial dan FiskalPer, 31 Desember 2019

\begin{tabular}{|c|c|c|c|c|c|}
\hline & komersial & Sebelum Pere & anaan Pajak & Setelah P & Perencanaan Pajal \\
\hline & & Koreksi Fiskal & Fiskal & Tax Planning & fiskal \\
\hline PENDAPATAN & & & & & \\
\hline Pendapatan jasa & 1.109 .457 .3 & & 1.109 .457 .300 & & 1.109 .457 .30 \\
\hline Pendapatan pokok & 949.141 .684 & & 949.141.684 & & 949.141 .684 \\
\hline Laba Kotor & 160.315 .616 & & 160.315 .616 & & 160.315 .616 \\
\hline Beban Jasa & & & & & \\
\hline Biaya Administrasi & & 15.973 .256 & & 12.413 .894 & \\
\hline Biaya Gaji & 25.000 .000 & & 9.026 .744 & & 21.440 .638 \\
\hline Biaya BPJS/Asuransi & 6.682 .000 & & 6.682 .000 & & 6.682 .000 \\
\hline Biaya Entertaiment & 20.400 .900 & & 20.400 .900 & & 20.400 .900 \\
\hline Biaya Penghapusan piutang & 11.600 .000 & 11.600 .000 & & 11.600 .000 & \\
\hline Biaya Penyusutan & $20.750,000$ & & $20.750,000$ & & $20.750,000$ \\
\hline Biaya Listrik,Air \& Telp & 2.509 .000 & & 2.509 .000 & & 2.509 .000 \\
\hline Biaya ATK & $1.556,000$ & & $1.556,000$ & & $1.556,000$ \\
\hline Biaya Pemeliharaan Kendaraan & 10.404 .712 & & 10.404 .712 & & 10.404 .712 \\
\hline Biaya Pulsa Karyawan & 5.800 .000 & & 5.800 .000 & & 5.800 .000 \\
\hline Total biaya & 104.702 .612 & & 77.129 .356 & & 89.543 .250 \\
\hline pendapatan lain-lain & & & & & \\
\hline Pendapatan lain-lain & 53.000 .000 & 21.200 .000 & 31.800 .000 & 21.200 .000 & 31.800 .00 \\
\hline Beban lain-lain & 14.560 .000 & & 14.560 .000 & & 14.560 .000 \\
\hline Laba Sebelum Pajak & 70.089 .146 & 48.773 .256 & 32.244 .11 & 45.213 .894 & 4.169 .146 \\
\hline
\end{tabular}


Dari tabel 1.2 dapat dijelaskan biaya-biaya yang dikoreksi positif yaitu:

1. Biaya entertainment sebesar Rp 20.400.900,-

2. Biaya pulsa / voucher karyawan dikoreksi $50 \%$ sebesar Rp 2.400.000,-

3. Biaya BBM dan service kendaraan (motor dan mobil) dikoreksi $50 \%$ sebesar $\mathrm{Rp}$ 5.200.312,- Semua biaya diatas masuk dalam biaya umum dan administrasi dengan total sebesar Rp15.973.256-

4. Biaya penghapus piutang dikoreksi positif sebesar Rp 11.600.000,-

5. Pendapatan lain-lain dikoreksi positif sebesar Rp 21.200.000,- yang diperoleh dari jumlah pendapatan bunga deposito Rp 21.200.000,-

Perencanaan pajak yang dilakukan perusahaan tahun 2019 yaitu dengan cara membuat daftar nominatif untuk biaya entertainment sebesar Rp 20.400.900,- sehingga dapat menjadi biaya fiskal atau dikoreksi negatif, pulsa/voucher karyawan dikoreksi 50\% Rp 2.400.000,- BBM dan service kendaraan (motor dan mobil) dikoreksi 50\% sebesar Rp 5.200.312,- biaya ini dijadikan tunjangan lain-lain dalam bentuk uang tunai sehingga seluruh biaya ini dapat dikoreksi negatif. Sebenarnya masih banyak biaya-biaya komersil tahun 2019 yang dikoreksi positif dapat menjadi koreksi negatif sehingga megurangi laba sebelum pajak seperti biaya rumah tangga kantor, biaya yang dikeluarkan perusahaan dalam rangka kesejahteraan karyawan yaitu seragam karyawan, dan biaya lain-lain yang sebagian besar mencakup pemberian sumbangan, tetapi dengan keterbatasan pengetahuan bagian keuangan perusahaan biaya-biaya tersebut tidak dilakukan koreksi. Dari data di atas kita dapat menghitung besarnya PPh Badan yang terutang sebagai berikut:

\section{Pembahasan Analisis Sebelum dan Setelah Perencanaan Pajak}

Dikarenakan Penghasilan Bruto Perusahaan dibawah Rp 4.800.000.000,- menurut Pasal 31E, dapat menggunakan perhitungan sebagai berikut dibawah ini:

Pada tahun 2019 kantor NOTARIS NINING HERLINA,SH.MKn memperoleh penghaslian kontor/bruto di bawah Rp.4.800.000.000 maka di lakukan perhitungan jumlah PKP yakni $50 \% \times 25 \% \times$ Penghasilan Rp.4.800.000.000 kena pajak, jika penghasilan kena pajak lebih dari 4.800.000.000 s/d 50.000.000.000 maka akan memperoleh fasilitas tambahan $25 \% \mathrm{x}$ penghasilan kena pajak tidak memproleh fasilitasuntuk $25 \%$ dikenankan untuk badan .

Tabel 1.3

Perbandingan Sebelum dan Setelah Perencanaan Pajak

\begin{tabular}{|c|c|c|c|}
\hline \multicolumn{2}{|c|}{ Sebelum Perencanaan Pajak } & \multicolumn{2}{|c|}{ Setelah Perencanaan Pajak } \\
\hline $\begin{array}{l}\text { Jumlah PKP yang } \\
\text { memperoleh } \\
\text { fasilitas adalah: } \\
50 \% \text { x } 25 \% \text { x Rp } \\
32.244 .110\end{array}$ & $\operatorname{Rp} 4.030 .513$ & $\begin{array}{l}\text { Jumlah PKP yang } \\
\text { memperoleh } \\
\text { fasilitas adalah: } \\
50 \% \text { x } 25 \% \text { x Rp } \\
4.169 .146\end{array}$ & $\operatorname{Rp} 521.143$ \\
\hline $\begin{array}{l}\text { Jumlah PKP yang } \\
\text { tidak memperoleh } \\
\text { fasilitas adalah: Rp } \\
32.244 .110-\mathrm{Rp} \\
4.030 .513\end{array}$ & Rp 28.213.597 & $\begin{array}{l}\text { Jumlah PKP yang } \\
\text { tidak memperoleh } \\
\text { fasilitas adalah: Rp } \\
4.169 .146-\mathrm{Rp} \\
521.143\end{array}$ & Rp 3.648.003 \\
\hline $\begin{array}{l}\text { Jadi PPh Badan } \\
\text { Pasal } 25 \text { yang } \\
\text { terutang adalah: } \\
50 \% \text { x } 25 \% \text { x Rp } \\
4.030 .513)+25 \% \\
\text { x Rp } 28.213 .597\end{array}$ & Rp 7. 557.213 & $\begin{array}{l}\text { Jadi PPh Badan } \\
\text { Pasal } 25 \text { yang } \\
\text { terutang adalah: } \\
50 \% \text { x } 25 \% \text { x Rp } \\
521.143+25 \% \text { x } \\
\text { Rp } 3.648 .003\end{array}$ & Rp 977.142 \\
\hline Laba setelah pajak & $\operatorname{Rp} 24.686 .897$ & Laba setelah pajak & $\operatorname{Rp} 3.192 .004$ \\
\hline
\end{tabular}




\begin{tabular}{l|l|l|l}
\hline \multicolumn{1}{c|}{ Sebelum Perencanaan Pajak } & \multicolumn{2}{c}{ Setelah Perencanaan Pajak } \\
\hline adalah: Rp & adalah: Rp & \\
$32.244 .110-\mathrm{Rp}$ & $4.169 .146-\mathrm{Rp}$ & \\
7.557 .213 & 977.142 & \\
\hline
\end{tabular}

Tabel 1.4

Persentase Penghematan PPh BadanSetelah Perencanaan Pajak

\begin{tabular}{c|c|c|c}
\hline Tahun & $\begin{array}{c}\text { Sebelum } \\
\text { Perencanaan Pajak }\end{array}$ & $\begin{array}{c}\text { Setelah } \\
\text { Perencanaan Pajak }\end{array}$ & $\begin{array}{c}\text { Persentase } \\
\text { Penghematan }\end{array}$ \\
\hline 2019 & 7.557 .213 & 977.142 & $87,1 \%$ \\
\hline
\end{tabular}

Adanya perencanaan pajak pada tahun 2019 ini maka banyak hal yang mempengaruhi PPh Badan yang terutang. Pajak terutang jauh lebih kecil dari sebelumnya senilai Rp 7.557.213,- dan di analisis lebih kecil sebesar Rp 977.142,- dengan nilai persentasi penghematan sebesar $87.1 \%$. Penghematan PPh Badan tersebut diperoleh karena biayabiaya komersil dapat dimaksimalkan untuk dikoreksi fiskal sehingga jumlah PPh Badan terutang dapat diminimalkan. Hal ini mempengaruhi laba bersih setelah pajak dan menjadi menurun dari Rp Rp 24.686.897 menjadi Rp 3.192.004,- dan memperoleh penghematan PPh Badan senilai $87.1 \%$.

\section{Keefektifan Perencanaan Pajak Yang Diterapkan pada Kantor NotarisNINING HERLINA SH.M.kn}

Ada beberapa usaha yang dilakukan Notaris NINING HERLINA SH.M.kn dalam meminimalkan beban pajak dengan beberapa hal seperti dibawah ini :

1. Analisis biaya komersil yang disinkronisasikan dengan analisis perhitungan fiskal agar nilai beban pajak dapat lebih minimal.

2. Mengontrol dan memonitoring setiap pelaksanaan perencanaan pajak setiap periodenya.. Berdasarkan dari analisis data yang dilakukan maka perencanaan pajak yang dilakukan Notaris NINING HERLINA SH.M.kn

3. dapat meminimalkan laba sebelum pajak sehingga dapat menghemat beban pajak terutangnya, tahun 2019 laba komersil sebelum pajak Rp 87.773.256 ,- setelah dikoreksi fiskal menjadi Rp 32.244.110.

\section{Penghematan Pajak yang sesuai dengan Undang-undang Pajak}

A. Pengertian Tax Planning

Perencanaan pajak adalah salah satu cara yang dapat dimanfaatkan oleh wajib pajak dalam melakukan manjemen perpajakan usaha atau penghasilannya, namun perlu diperhatikan bahwa perencaan pajak yang dimaksud adalah perencanaan pajak tanpa melakukan pelanggaran konstitusi atau Udang-Undang Perpajakan yang berlaku. Ketidakpatuhan terhadap undang-undang dapat dikenakan sanksi administrasi maupun sanksi pidana. Tetapi kedua sanksi itu merupakan pemborosan sumber daya sehingga perlu dieliminasi melalui tax planning yang baik. Maka dalam rangka optimalisasi alokasi sumber dana manajemen akan dilakukan perencanaan pembayaran yang tidak lebih (dapat mengurangi optimalisasi alokasi sumber daya) dan tidak kurang (supaya tidak membayar sanksi administrasi yang merupakan pemborosan dana).

B. Tujuan Penyusunan Tax Planning (Perencanaan Pajak)

Tujuan penyusunan Tax Planning (Perencanaan Pajak) bagi perusahaan (Wajib Pajak) antara lain :

1. Agar perhitungan pajak atau pajak yang harus dibayar oleh perusahaan (Wajib Pajak) benar atau sesuai peraturan perpajakan yang berlaku sehingga apabila dilakukan penelitian atau pemeriksaan oleh kantor pajak tidak ada pajak yang harus dibayar lagi 
dan tidak menimbulkan sanksi perpajakan bagi Perusahaan (Wajib Pajak).

2. Agar Pajak yang harus dibayar oleh perusahaan (Wajib Pajak) menjadi lebih kecil, maka dilakukan dengan cara memanfaatkan celah (kelemahan) yang ada dalam peraturan perpajakan tanpa melanggar peraturan perpajakan tersebut.

3. Dengan melaksanakan Tax Planning (Perencanaan Pajak) yang tepat, maka Perusahaan (Wajib Pajak) dapat menurunkan beban pajak yang pada akhirnya akan meningkatkan laba setelah pajak.

C. Peraturan Pajak

Untuk merealisasikan tax planning (perencanaan pajak) yang tidak melanggar peraturan perpajakan, maka perlu pemahaman tentang peraturan perpajakan itu sendiri, karena peraturan perpajakan yang membuat manusia maka dimungkinkan adanya celah (kelemahan) dalam peraturan yang dapat dimanfaatkan oleh Perusahaan (Wajib Pajak) untuk menghindari pajak tanpa melanggar Peraturan Pajak. Peraturan perpajakan yang dimaksud adalah :

1. Undang-Undang Perpajakan.

Undang-Undang Perpajakan adalah Undang-Undang yang mengatur tentang Pajak, meliputi :

a. Undang-Undang Nomor 28 Tahun 2007 Tentang KUP (Ketentuan Umum dan Tata Cara Perpajakan).

b. Undang-Undang Nomor 36 Tahun 2008 Tentang PPh (Pajak Penghasilan).

c. Undang-Undang Nomor 42 Tahun 2009 Tentang PPN (Pajak Pertambahan Nilai) dan PPnBM (Pajak Penjualan Atas Barang Mewah).

2. PERPU (Peraturan Pengganti Undang-Undang).

PERPU Peraturan Pengganti Undang-Undang yang mengatur tentang Perpajakan.

3. PP (Peraturan Pemerintah)

PP (Peraturan Pemerintah) yang mengatur tentang Perpajakan.

4. PMK (Peraturan Menteri Keuangan)

PMK (Peraturan Menteri Keuangan) yang mengatur tentang Perpajakan.

5. KMK (Keputusan Menteri Keuangan)

KMK (Keputusan Menteri Keuangan) yang mengatur tentang Perpajakan.

6. PER Dirjend Pajak (Peraturan Direktur Jenderal Pajak)

PER Dirjend Pajak (Peraturan Direktur Jenderal Pajak) yang mengatur tentang Perpajakan.

7. KEP Dirjend Pajak (Keputusan Direktur Jenderal Pajak)

KEP Dirjend Pajak (Keputusan Direktur Jenderal Pajak) yang mengatur tentang Perpajakan.

8. Tax Treaty atau P3B (Persetujuan Penghindaran Pajak Berganda).

Tax Treaty atau P3B (Persetujuan Penghindaran Pajak Berganda) mengatur tentang subjek pajak, objek pajak dan tarif pajak penghasilan atas penghasilan yang diterima Wajib Pajak Luar Negeri.

D. Syarat Penyusunan Tax Planning (Perencanaan Pajak) Yang Baik

Untuk menyusun Tax Planning (Perencanaan Pajak) yang baik diperlukanpersyaratan sebagai berikut :

1. Memahami Proses Bisnis Perusahaan (Wajib Pajak)

Untuk menyusun Tax Planning (Perencanaan Pajak) perlu terlebih dahuulu memahami bagaimana proses bisnis dari kegiatan usaha Perusahaan (Wajib Pajak) Dengan memahami proses bisnis, diharapkan Tax Planning (Perencanaan Pajak) yang disusun tidak bertentangan dengan kebijakan bisnis perusahaan (Wajib Pajak).

2. Memahami Peraturan Pajak yang terkait dengan Kegiatan Usaha Perusahaan (Wajib Pajak)

Dengan memahami Peraturan Pajak yang terkait dengan Kegiatan Usaha Perusahaan 
(Wajib Pajak), maka akan memudahkan penyusunan Tax Planning (Perencanaan Pajak).

3. Menentukan Tujuan Yang Ingin Dicapai Dalam Tax Planning (Perencanaan Pajak)

Perusahaan (Wajib Pajak) harus terlebih dahulu menentukan Tujuan yang ingin dicapai untuk memudahkan penyusunan Tax Planning (Perencanaan Pajak).

E. Jenis Tax Planning (Perencanaan Pajak)

1. National Tax Planning.

National Tax Planning adalah Tax Planning (Perencanaan Pajak) yang dilakukan oleh Perusahaan (Wajib Pajak) yang mempunyai kegiatan usaha di Indonesia saja atau yang mempunyai transaksi dengan Perusahaan (Wajib Pajak) dalam negeri saja. Tax Planning (Perencanaan Pajak) dilakukan dengan berdasarkan peraturan perpajakan yang berlaku di Indonesia, yaitu antara lain :

a. Undang-Undang Nomor 28 Tahun 2007 Tentang KUP dan peraturan pelaksanaannya.

b. Undang-Undang Nomor 36 Tahun 2008 Tentang PPh dan peraturan pelaksanaannya.

c. Undang-Undang Nomor 42 Tahun 2009 Tentang PPN dan PPnBM serta peraturan pelaksanaannya.

2. International Tax Planning.

International Tax Planning adalah Tax Planning (Perencanaan Pajak) yang dilakukan oleh Perusahaan (Wajib Pajak) yang mempunyai kegiatan usaha di Indonesia dan di Luar Negeri. Sehingga Perusahaan (Wajib Pajak) ini selain melakukan transaksi dengan Perusahaan (Wajib Pajak) dalam negeri juga melakukan transaksi dengan Perusahaan (Wajib Pajak) Luar Negeri baik yang berkedudukan di Indonesia maupun di Luar Indonesia. Tax Planning (Perencanaan Pajak) dilakukan dengan berdasarkan peraturan perpajakan yang berlaku di Indonesia dan Tax Treaty atau P3B (Persetujuan Penghindaran Pajak Berganda) yang berlaku antara Indonesia dengan Negara dimana lawan transaksi tersebut berada, yaitu antara lain:

a. Undang-Undang Nomor 28 Tahun 2007 Tentang KUP dan peraturan pelaksanaannya.

b.Undang-Undang Nomor 36 Tahun 2008 Tentang PPh dan peraturan pelaksanaannya.

c.Undang-Undang Nomor 42 Tahun 2009 Tentang PPN dan PPnBM serta peraturan pelaksanaannya.

d.Tax Treaty atau P3B (Persetujuan Penghindaran Pajak Berganda).

\section{SIMPULAN}

1. Dari analisis tentang perencanaan pajak dan dengan adanya koreksi fiskal terhadap laporan keuangan Notaris NINING HERLINA SH.M.kn maka dapat ditarik kesimpulan yaitu perencanaan pajak yang efektif dapat dihasilkan melalui analisis terhadap laporan keuangan dengan cara melakukan koreksi yang maksimal terhadap laporan keuangan seperti dengan penyesuaian biaya-biaya komersil dapat dimaksimalkan untuk dikoreksi fiskal dengan mengikuti peraturan yang telah ditetapkan oleh pemerintah.

2. Perencanaan pajak merupakan suatu cara dalam meminimalisasi besarnya pajak terutang. Perencanaan pajak adalah suatu cara yang legal untuk dilakukan selama dalam pelaksanaanya masih tetap berada dalam bingkai ketentuan perpajakan. Perencanaan pajak 


\section{DAFTAR PUSTAKA}

Anonim, 2020, "Buku Pedoman Peraktek Kerja Lapangan (PKL)", Program Studi DIII Perpajakan Fakultas Ekonomi dan Bisnis, Universitas Mataram.

2007. Undang-Undang Republik Indonesia Nomor 28 Tahun 2007tentang "Ketentuan Umum dan Tata Cara Perpajakan".

-2008. Undang-Undang Republik Indonesia Nomor 36 Tahun 2008tentang"Pajak Penghasilan dan Pelaksanaannya".

Anonim, 2009. UU PPh No. 17 th. 2000 pasal 17 Tarif Pajak Setelah Tahun 2009 Mardiasmo, 2018 "Tentang pengantar perpajakan ".

------------2019 "perpajakan "

Sophar lumbantoruan,2000 edisi revisi " Akuntasi pajak "

Resmi, Siti 2011, Perpajakan Teori dan Kasus, Buku 1, Edisi 6, Salemba Empat, Jakarta Resmi, Siti 2013, Perpajakan Teori dan Kasus, Buku 1, Edisi 7, Salemba Empat, Jakarta Sugiyono, 2008, Metode Penelitian Kuantitatif, Kualitatif dan R\&D,Alfabeta, Bandung 